HorTSCIENCE 26(11):1383-1386. 1991.

\title{
Use of Greenhouse Seedling Bioassays to Predict First Year Growth of Apple Trees Planted in Old Orchard Soil
}

\author{
G.H. Neilsen ${ }^{1}$, J. Beulah ${ }^{2}$, E.J. Hoguel, and R.S. Utkhede ${ }^{1}$ \\ Agriculture Canada Research Station, Summerland, B.C. VOH $1 Z 0$ \\ Canada
}

Additional index words. replant disorder, pot test, total shoot, growth, Malus domestica

\begin{abstract}
Apple seedling height after 7 weeks of growth in greenhouse pots was compared with total first year shoot growth of 'McIntosh' or 'Delicious' apple trees [ Malus domestica (Borkh.)] on M.26 rootstock for eight orchards and five soil treatments. The apple trees were replanted in old orchard sites with the same treatments applied in the planting hole as were tested in the greenhouse. The pot test successfully predicted treatments that increased first year shoot growth in 23 of 30 opportunities. However, a less precise relationship $\left(R^{2}=0.38\right)$ existed between total first year shoot growth $(Y)$ of 'Summerland Red McIntosh' on M.26 rootstock and seedling height (X).
\end{abstract}

Seedling bioassay tests to predict potential replant problems were originally developed

Received for publication 19 Feb. 1991. Contribution no. 775 of Agriculture Canada, Research Station, Summerland, B.C. We acknowledge the financial assistance of the Canada/British Columbia Subsidiary Agreement on Agri-Food Regional Develooment (ARDSA 1989-901 and the British Columbia Fruit Growers' Assn. 'The late J. Yorston was instrumental in obtaining funding for this project. The cost of publishing this paper was defrayed in part by the payment of page charges. Under postal regulations, this paper therefore must be hereby marked advertisement solely to indicate this fact.

${ }^{1}$ Research Scientist.

${ }^{2}$ Research Associate ARDSA project 11016. on a state-wide scale in Holland (Hoestra, 1968) and subsequently used in Australia (Sitepu and Wallace, 1974), Belgium (Gilles, 1989), and England (Upstone, 1975). The tests were developed to assess the potential for soils to respond to replant treatments, usually involving fumigation. The growth of seedlings over a short time interval (usually 2 to 3 months) under greenhouse conditions in treated and untreated soil was used as an indicator of the response to be expected in the field. As has been long recognized, the usefulness of the bioassay depends on the relationship between greenhouse and field responses (Savory, 1967). Only a few correlation studies have been made of field and laboratory results with generally good agree- 
Table 1. Chemical properties of soil samples collected from eight replanted orchards.

\begin{tabular}{|c|c|c|c|c|c|c|c|c|}
\hline \multirow{2}{*}{$\begin{array}{l}\text { Soil property } \\
\text { (unit) }\end{array}$} & \multicolumn{8}{|c|}{ Orchard } \\
\hline & 68 & 69 & 70 & 71 & 72 & 73 & 74 & 75 \\
\hline $\begin{array}{l}\mathrm{pH}(1 \text { soil : } 2 \text { water }) \\
\mathrm{P}\left(\mu \mathrm{g} \cdot \mathrm{ml}^{-1}\right)^{\mathbf{z}} \\
\mathrm{K}\left(\mu \mathrm{g} \cdot \mathrm{ml}^{-1}\right)^{\mathrm{z}} \\
\mathrm{Mg}\left(\mu \mathrm{g} \cdot \mathrm{ml}^{-1}\right)^{\mathbf{z}} \\
\mathrm{Ca}\left(\mu \mathrm{g} \cdot \mathrm{ml}^{-1}\right)^{\mathrm{z}} \\
\mathrm{B}\left(\mu \mathrm{g} \cdot \mathrm{ml}^{-1}\right)^{\mathrm{y}} \\
\text { Organic matter }(\%)^{x} \\
\text { Electrical conductivity } \\
\quad\left(\mathrm{dS} \cdot \mathrm{m}^{-1} 1 \text { soil }: 2 \text { water }\right)\end{array}$ & $\begin{array}{c}6.9 \\
43 \\
221 \\
122 \\
896 \\
0.28 \\
2.4 \\
0.32\end{array}$ & $\begin{array}{c}7.5 \\
16 \\
133 . \\
129 \\
912 \\
0.34 \\
1.0\end{array}$ & $\begin{array}{c}6.5 \\
77 \\
214 \\
220 \\
1167 \\
0.44 \\
3.0\end{array}$ & $\begin{array}{c}6.8 \\
18 \\
369 \\
792 \\
3027 \\
0.51 \\
4.8\end{array}$ & $\begin{array}{c}8.0 \\
44 \\
188 \\
256 \\
2735 \\
0.72 \\
3.5\end{array}$ & $\begin{array}{c}7.3 \\
23 \\
75 \\
114 \\
735 \\
0.37 \\
1.2\end{array}$ & $\begin{array}{c}6.5 \\
86 \\
436 \\
439 \\
1566 \\
0.08 \\
4.7 \\
\\
0.64\end{array}$ & $\begin{array}{c}7.0 \\
37 \\
159 \\
78 \\
816 \\
0.53 \\
1.1 \\
\\
0.64\end{array}$ \\
\hline
\end{tabular}

${ }^{\mathrm{x}}$ As extracted with $0.25 \mathrm{~N}$ acetic and $0.015 \mathrm{~N} \mathrm{NH}_{4} \mathrm{~F}$ (Kelowna extractant).

yAs extracted in boiling water $(5 \mathrm{~min})$.

Determined by loss on ignition at $450 \mathrm{C}$.

Table 2. Mean height of apple seedlings, grown in eight old orchard soils for 7 weeks under greenhouse conditions after various soil treatments.

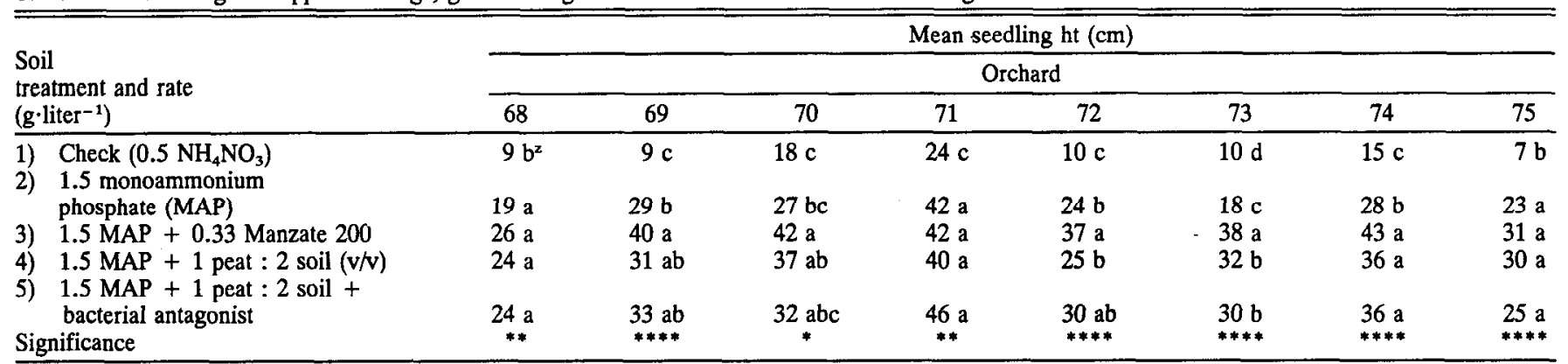

${ }^{2}$ Mean separation in a given orchard (column) at $P=0.05\left({ }^{*}\right), 0.01\left({ }^{* *}\right)$, or $0.001\left(^{* * * *}\right)$. Data shown are means of six observations.

Table 3. Mean total first year shoot growth of 'Summerland Red McIntosh' on M.26 replanted in eight orchards and grown with the same planting hole treatments as were tested under greenhouse conditions.

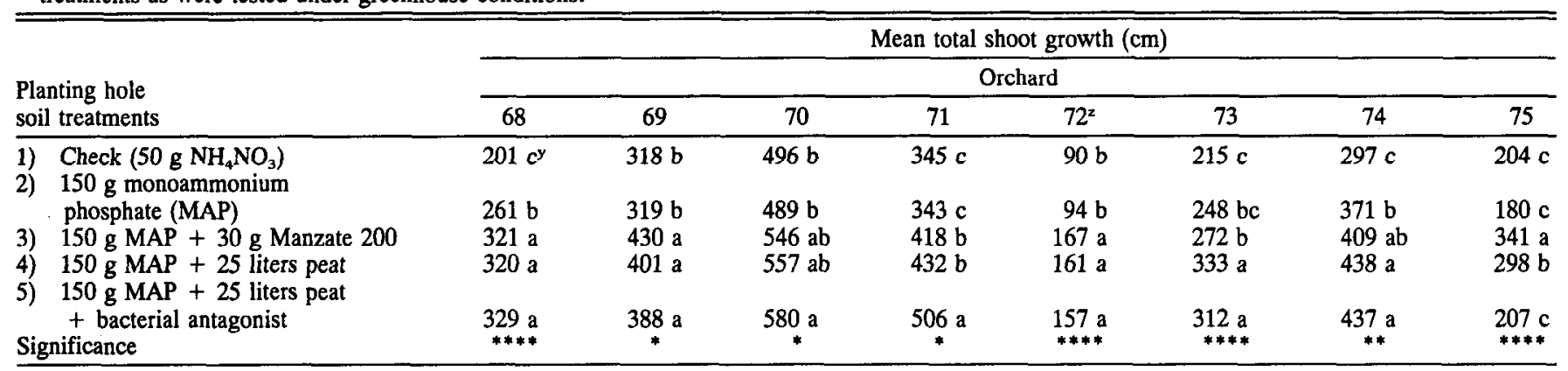

'Ace Red Delicious' on M.26 replanted in this orchard.

yMean separation in a given orchard (column) at $P=0.05\left({ }^{*}\right), 0.01\left({ }^{* *}\right)$, or $0.00001\left(^{* * * *}\right)$. Data shown are means of 20 trees (five-replicate, four-tree plots).

ment reported from Holland (Hoestra, 1968) and England (Savory, 1967), although Sewell and White (1979) also reported greater growth responses to formalin in the field than was predicted from pot studies.

In the Pacific Northwest, Slykhuis and $\mathrm{Li}$ (1985) relied extensively on 14-week Antonovka apple seedling bioassays to predict growth response to biocides and phosphate fertilizers in old orchard soils. Much less information is available concerning subsequent growth of such treated trees in the orchard. Consequently, this study reports detailed comparisons made between responses predicted from a greenhouse apple seedling bioassay test and first year 'McIntosh' apple tree growth for a range of treatments in eight orchards located throughout the fruit growing area of the Okanagan and Similkameen valleys of British Columbia.

Composite soil samples, which exhibited a range of soil properties (Table 1), were collected in Fall 1988 from the midrow area of the 0 - to $30-\mathrm{cm}$ soil layer in eight replanted orchard blocks from which apple trees had been removed in Fall 1987. An excep tion was orchard 72 , from which trees were removed in Fall 1986. All soils were passed through a 6-mm sieve to remove large gravel. Sufficient soil from each orchard was amended with one of five treatments to result in six replicate 0.5 -liter pots per treatment. Treatments were (g.liter ${ }^{-1}$ ) 1) 0.5 ammonium nitrate $(34 \mathrm{~N}-0 \mathrm{P}-0 \mathrm{~K}$, control), 2) 1.5 monoammonium phosphate (MAP, $11 \mathrm{~N}-$ 24P-0K), 3) 1.5 MAP plus 0.33 Manzate 200 ( $\mathrm{Zn}, \mathrm{Mn}$ ethylene bisdithiocarbamate), 4) 1.5 MAP to a 1 peat : 2 orchard soil mixture (v/v), and 5) 1.5 MAP to a 1 peat : 2 orchard soil mixture to which a crown rot antagonistic bacterium, Enterobacter aerogenes (Kruse) Honaeche and Edwards (B8), had been added. The antagonistic bacterium was cultured on Difco dextrose agar at 30C for $48 \mathrm{~h}$. The culture was removed from the petri dishes using a glass rod and suspended in distilled water. The applied bacterial suspension was $1.6 \times 10^{9}$ colony forming units (CFU) per pot (10 $\mathrm{ml}$ bacterial suspension).

'McIntosh' apple seeds, stratified at 5C for 10 weeks were germinated in a 1 peat : 1 perlite mixture and at the two-leaf stage were transferred (one per pot) to each treatment pot. The five treatments were arranged in a randomized complete-block design with six replicates for each orchard. The seedlings were grown for 7 weeks in a greenhouse with $16 \mathrm{~h}, 24 \mathrm{C}$ days and $8 \mathrm{~h}, 18 \mathrm{C}$ nights with a minimum light intensity of $\approx 160$ $\mu \mathrm{mol} . \mathrm{m}^{-2} \cdot \mathrm{s}^{-1}$. Pots were checked daily and watered as required. White flies [Trialeurades vapororiorum (Westwood)], aphids [Myzus persicae (Salze)], and spider mites [Tebranychus mcdaniele (McGregor)] were controlled biologically by Encarsia formosa (Gaban), Aphiodoletes aphidimyza (Ron- 


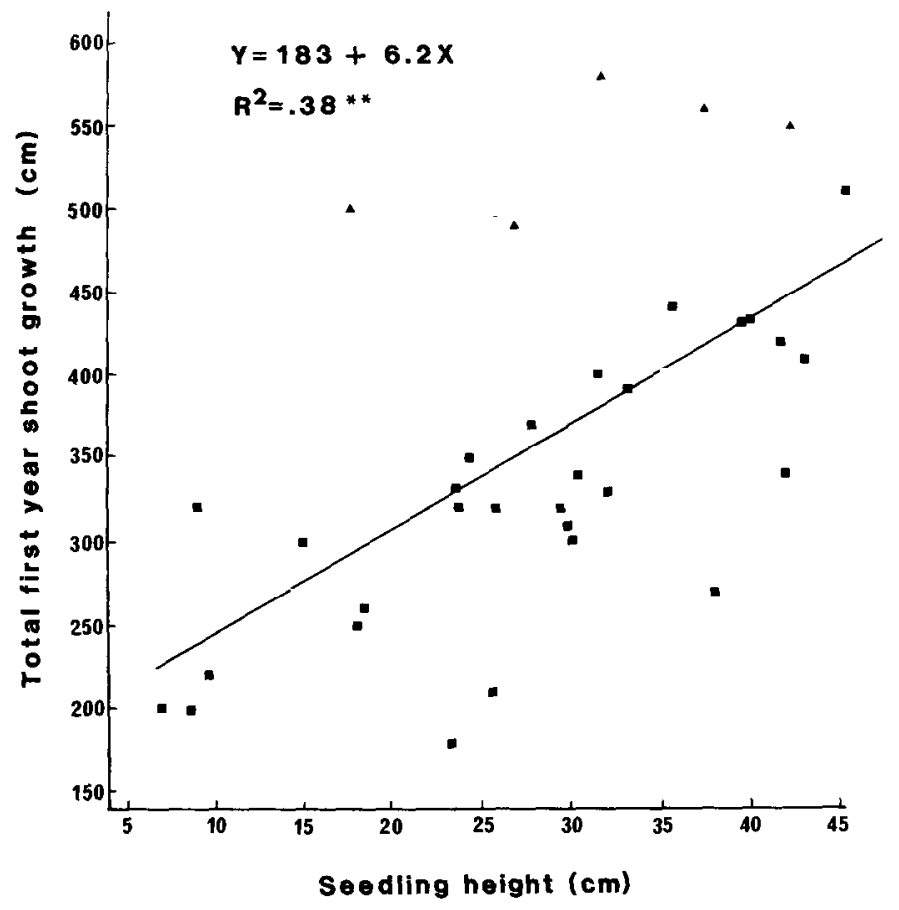

Fig. 1. Relationship between average first year total shoot growth of 'Summerland Red McIntosh' on M. 26 rootstock and average height of apple seedlings grown for 7 weeks under greenhouse conditions for five treatments in seven orchards. Significance at $P<0.01\left(^{* *}\right) ; \Delta$, values for orchard 70; $\boldsymbol{a}$, other six orchards. Total shoot growth values are the mean of 20 trees while seedling heights are the means of six replicates.

odani), and Phytoseiulus persimilis (AthiasHenriot), respectively. Two Bayleton [1-(4chlorophenoxy)-3, 3-dimethyl-1-(1H-1,2,4[trizol-1-yl-)-2-butanone] sprays at 0.1 g-liter ${ }^{-1}$ were applied to control powdery mildew. At 7 weeks, height, top, and root fresh and dry weight were recorded for each seedling.

Experimental plots had been established in Mar.-Apr. 1988 in the same eight orchards, henceforth referred to as orchards 68-75. These orchards were selected on the basis of good quality orchard management. The five treatments, previously described, were arranged in a randomized complete block design with five-replicate, four-tree plots. Treatments were applied in the tree planting hole, at rates adjusted to the volume of the planting hole. Thus, the control treatment (1) involved application of $50 \mathrm{~g}$ of ammonium nitrate $(34 \mathrm{~N}-0 \mathrm{P}-0 \mathrm{~K})$ while MAP application to treatments $2-5$ was $150 \mathrm{~g}$. Manzate 200 at $30 \mathrm{~g}$ was also applied for treatment 3 . The fertilizers and fungicide were uniformly mixed in soil removed from the planting hole. The treatments with peat (4 and 5) also included mixing of 25 liters of peat in the planting hole with this mixture removed for MAP fertilizer addition before the reapplication upon tree placement. The antagonistic bacterium in treatment 5 was applied as a soil drench 1 week following planting and again in Sept. 1988. The previously described bacterial suspension containing $1.6 \times 10^{9} \mathrm{CFU}$ was applied around the tree roots with 1 liter of water.

'Summerland Red McIntosh' whips on M.26 rootstock were planted with the graft $\approx 4.5 \mathrm{~cm}$ above the soil surface in all except orchard 72. In this orchard, "Ace Red Delicious' on M.26 was planted. Postplanting management of the experimental blocks was undertaken by each cooperating orchardist to maximize growth of the young trees. The field sites were monitored every 2 weeks throughout the growing season. With the exception of orchard 68 , foliar nutrient sprays of $\mathrm{N}, \mathrm{Zn}, \mathrm{Mg}$, and B were frequently applied to the young trees. All orchard floor vegetation was controlled in the tree row throughout the growing season in all orchards, except 70 to 73 inclusive, where some weed regrowth was observed. Foliar disease problems were slight, except in orchards 73 and 75 , which had powdery mildew. Insect problems were limited to a high aphid population at the end of the growing season in orchard 72. Irrigation ranged from solid set or portable pipe (orchard 75) to trickle irrigation (orchards 70 and 71) but was adequate at all sites. In general, orchard management ranged from good to excellent and we judged that it had not differentially affected treated trees. In Oct. 1988, total shoot growth and trunk diameter at $0.3 \mathrm{~m}$ height above the graft union were measured for all experimental trees.

Analysis of variance was undertaken on all greenhouse and field growth data according to the appropriate experimental design.

In the greenhouse, seedling height and top fresh weight were highly correlated $(r=0.97$, $P<0.01)$, whereas a similar high correlation between trunk diameter and total shoot growth $(r=0.92, P<0.01)$ was observed in the field. Consequently, seedling height in the greenhouse and total shoot growth in the field were the single growth variables selected for subsequent comparison.
In the greenhouse pot test, all treatments produced a statistically significant $(P<0.05)$ increase in growth (height) except for two treatments from orchard 70 (Table 2). Exceptions were the MAP and MAP + peat + bacterial antagonist treatments, which failed to result in significant seedling growth increases in orchard 70. There were also few statistical differences between noncontrol treatments, although application of MAP alone did not improve growth as much as the MAP + Manzate treatment in orchards 69, 72, and 73 , or as much as did various treatments combined with MAP in orchards 73 and 74 (Table 2). Also, in orchard 73, MAP + Manzate was the best treatment in the greenhouse. Sewell et al. (1988), in the United Kingdom, recommend field application of replant treatments for dwarfing rootstocks such as M.26 when the ratio between treated and untreated seedlings grown for 12 weeks exceeded $150 \%$. Using this U.K. criterion, field treatment would have been recommended for our greenhouse data in 31 tested orchardtreatment combinations. As a result, the only difference between greenhouse recommendations based on statistical or percentage growth increases was the bacterial antagonist treatment in orchard 70. Using the statistical criterion, the bacterial antagonist treatment would not have been recommended in orchard 70

Significant $(P<0.05)$ increases in total shoot growth relative to untreated trees were measured in the field at the end of the first growing season in $77 \%$ (23 of 30) (Table 3) of treatments that would have been recommended on the basis of statistical analysis of mean seedling height in the greenhouse. Five false recommendations were associated with MAP fertilization: greenhouse tests suggested responses to MAP that were not apparent in the field after the first growning season. However, the pot test correctly predicted the lack of MAP response in orchard 70. In other deviations, MAP + Manzate and MAP + peat did not achieve the greenhouse predicted response in the field in orchard 70, while MAP + peat + bacterial antagonist performed poorly in orchard 75 and better than predicted in orchard 70 . Orchard 70 had the best growth in the field, suggesting a less severe incidence of a replant problem and reduced potential for growth improvements via planting hole treatments. In five of eight orchards there were no differences among first year total shoot growth averages for the three treatments involving combinations of MAP and peat, Manzate, or peat + bacterial antagonist. Exceptions were the superior first year performance of MAP + Manzate in Orchard 75 , and of MAP + peat + bacterial antagonist in orchard 71. In orchard 73, MAP + Manzate was less effective than the other two treatments.

In general, these results suggest that, with a few exceptions, the pot test was quite successful in predicting planting hole treatments that would improve first year tree growth. Similar conclusions concerning the usefulness of a seedling bioassay test were made 
by Hoestra (1968) who used apple seedlings to predict growth response of apples on chloropicrin-fumigated replant problem soils in Holland. However, our data suggest seedling growth to be sensitive to $\mathrm{P}$ fertilization but may overpredict response to $\mathrm{P}$ in the field where roots grow into untreated soil. The development of bioassay tests for apple replant disorder, as in England (Sewell et al. 1988), can avoid such problems by periodically supplying apple seedlings with nutrient solutions containing $\mathrm{P}$. The value of MAP fertilization in replant field situations has, however, been indicated by its presence in combination treatments that increased tree growth in the first year (Table 3).

The pot test also showed considerable variation in growth between orchards, for control treatments by a 3- to 4-fold growth difference in seedling height for control treatments that ranged from a low of $7 \mathrm{~cm}$ for orchard 75 to a high of $24 \mathrm{~cm}$ for orchard 71 (Table 2). Untreated soil from orchards 70,71 , and 74 supported better seedling growth $(>15 \mathrm{~cm})$ than other untreated soils. Actual field growth for control trees also showed a wide variation in the first year total shoot growth with a range from a low of 90 $\mathrm{cm}$ in orchard 72 to a high of $496 \mathrm{~cm}$ in orchard 70 (Table 3). Best growth was near or in excess of $300 \mathrm{~cm}$ and was measured in orchards $69,70,71$, and 74 . The general pattern of check tree growth was similar to that predicted by the pot experiment, although trees in orchard 69 performed better than expected from greenhouse results. This evidence implies a pot test has some value for discriminating potential variation in severity of replant problems.

However, there does not seem to be an exact correlation between first year shoot growth $(\mathrm{Y})$ and greenhouse seedling height (X). For all treatments in all orchards, a statistically significant predictive relationship between the two variables was expressed as $\mathrm{Y}=146+6.6 \mathrm{X}$ with the proportion of variance explained $\left(R^{2}\right)$ at $0.31^{* *}, P<0.01$ (data not shown). For this relationship, first year shoot growth in orchard 72 was much less than predicted from the general equation above. This orchard had a different cultivar ('Ace Red Delicious'), implying that a different field-greenhouse relationship may exist for each cultivar. Improved prediction $\left(\mathrm{R}^{2}\right.$ $\left.=0.38^{* *}, P<0.01\right)$ results when considering only orchards with 'Summerland Red McIntosh' on M.26 rootstock (Fig. 1). Nevertheless, considerable variation in the relationship was also noted with first year shoot growth for the five treatments in orchard 70 ( $\boldsymbol{\Delta}$, Fig. 1), which exhibited a less severe replant problem, better than predicted from the greenhouse experiment. In general, these observations suggest an inexact relationship between field and pot tests with differences between pot and field growth likely related to differential behavior of cultivarrootstock combinations and lack of an unequivocal indication of disorder severity via the seedling test. This weakness of the pot test was previously noted by Hoestra (1968), who also indicated that it was not surprising in view of the widely different growth conditions in the field relative to the greenhouse. Field growth, for example, occurs under conditions where field bulk density can differ from the potted soil and where tree roots can grow into untreated soil areas.

In summary, this short-term (7-week) apple seedling bioassay had a success rate $>75 \%$ in predicting treatments that would improve first year tree growth. Such success was achieved despite the shorter duration and the wider range of treatments than the 12-week test used to make the narrower assessment of whether or not to fumigate orchard soils in Europe (Upstone, 1975). Furthermore, this consistency was achieved in orchards with a range of soils, nutrient levels, and organic matter content (Table 1). Although generally indicating the variation of growth to be expected from orchard to orchard, the correlation between eventual first year tree growth and seedling height in the greenhouse was less precise. Variation in cultivar-rootstock response and in severity of replant disorder form greenhouse to field were two factors associated with this imprecision. Nevertheless, use of seedling bioassay can provide useful information when replanting apples in old orchard soil.

\section{Literature Cited}

Gilles, G.L. 1989. Problèmes de replantation en culture fruitière. Revue de l'Agriculture Landbouwtigdschrift 42:179-185.

Hoestra, H. 1968. Replant disease of apple in the Netherlands. Med. Lanb. Wageningen, 68-13.

Savory, B.M. 1967. Specific replant diseases of apple and cherry. Rpt. E. Malling Res. Sta. 1966(1967):205-208.

Sewell, G.W.F. and G.C. White. 1979. The effects of formalin and other soil treatments on the replant disease of apple. J. Hort. Sci. 54:333335.

Sewell, G.W.F., D.A. Preece, and R.F. Elsey. 1988. Apple replant disease: the influence of soil phosphorus and other factors on the growth responses of apple seedlings to soil fumigation with chloropicrin. Ann. Applied Biol. 103:605615 .

Sitepu, D. and H.R. Wallace. 1974. Diagnosis of retarded apple growth in an apple orchard. Austral. J. Expt. Agr. Animal Husbandry 14:577584.

Slykhuis, J.T. and T.S.C. Li. 1985. Responses of apple seedlings to biocides and phosphate fertilizers in orchard soils in British Columbia. Can. J. Plant Pathol. 7:295-301.

Upstone, M.E. 1975. The testing of orchard soils for specific replant disease. 1965-74. Rpt. ADAS Sci. Serv. 1974, HMSO, London. p. 181-185. 